\title{
Pengaruh Bank-spesific Factors dan Kondisi Ekonomi terhadap Kinerja Maqashid Syariah BUS di Indonesia
}

\author{
The influence of bank-specific factors and economic conditions on the performance of maqashid \\ sharia BUS in Indonesia for the 2014-2018 period
}

\section{Fitri Syahbani Rozak}

Program Studi D4 Keuangan Syariah, Politeknik Negeri Bandung

E-mail: syahbanifitri@gmail.com

\section{Fatmi Hadiani}

Jurusan Akuntansi, Politeknik Negeri Bandung

E-mail: fatmi.hadiani@polban.ac.id

\section{Setiawan}

Jurusan Akuntansi, Politeknik Negeri Bandung

E-mail: setiawan@polban.ac.id

\begin{abstract}
Islamic banking is a financial institution based on Sharia principles. Therefore, a measurement of the performance of Islamic banking needs to be distinguished from the measurement of the performance of conventional banking. This performance is not only the performance in generating profits, but rather the performance of Islamic banks in meeting social benefits. This performance can be measured by the maqashid sharia index. The policies of each bank are different because the internal conditions of a bank are not the same and each bank also faces different macroeconomic conditions every year. This study aims to determine the effect of bank-specific factors represented by bank size and CAR and macroeconomic conditions represented by GDP, inflation and exchange rates on the Islamic maqashid index. The object of this research is Islamic Commercial Banks in Indonesia which consistently operate as BUS during the period 2014 to 2018. The type of data used is secondary data obtained from the annual reports of each BUS, BPS statistical data and BI statistics. This research method uses descriptive quantitative with panel data regression analysis techniques. The results of this study indicate that bank size, inflation and exchange rates, do not have a significant effect on the performance of Islamic Maqashid. Meanwhile, the CAR and GDP have a significant negative and positive effect on the performance of Maqashid Syariah.
\end{abstract}

Keywords: Islamic commercial bank, bank-specific factors, macroeconomic, maqashid syariah

\section{Pendahuluan}

Seiring waktu pertumbuhan BUS di Indonesia mengalami kemajuan. Hal ini menjadikan BUS menghadapi persaingan secara langsung dengan Bank Konvensional. Jika dibandingkan Bank Syariah dengan Bank Konvensional tentu berbeda, terutama pada pengukuran kinerjanya. Bank Syariah dengan aset yang besar tidak dapat dikatakan bahwa akan menghasilkan kinerja yg paling baik. Hal ini tentu tergantung dari jenis penilaian kinerjanya. Mengingat Bank Syariah adalah lembaga keuangan yg menjalankan prinsip - prinsip Syariah, sudah seharusnya pengukuran kinerjanya pun sesuai dengan Syariah. Hal ini berkaitan dengan tujuannya yg bukan hanya mengejar profitabilitas namun lebih dari pada itu harus mampu menciptakan maslahah umum. Perbankan Syariah diharapkan memberikan kontribusi terhadap perbaikan kondisi perekonomian (Setiawan, 
Wulansari \& Dewi, 2020). Menurut Antonio (2012) Bank Syariah harus dapat menyeimbangkan antara urusan dunia (profit) dan urusan surga (kepentingan umum). Oleh karena itu banyak penelitian mengenai penilaian kinerja khusus untuk Bank Syariah, salah satunya menggunakan Maqashid Syariah Index (MSI).

Penggunaan alat ukur berupa Maqashid Syariah Index (MSI) memiliki beberapa kelebihan apabila dibandingkan dengan alat ukur Bank Konvensional. Jika menggunakan rasio keuangan konvensional sebagai penilaian kinerja utama akan menjadikan perusahaan mengabaikan rencana jangka panjang dan terhambat untuk mencapai tujuannya di masa depan (surga), karena hanya fokus pada profitabilitas saja (duniawi). Dengan demikian pengukuran ini menjadi sangat penting seperti yang dikemukakan oleh Mohammed (2008) dan Gayatri \& Sutrisno (2017). Mereka menyebutkan bahwa pengukuran kinerja bagi Perbankan Syariah ini tidak hanya berfokus pada laba dan ukuran keuangan lainnya, akan tetapi dimasukkan nilai-nilai lain dari perbankan yang mencerminkan ukuran manfaat nonprofit yang sesuai dengan tujuan Bank Syariah.

Pada penelitian sebelumnya menyebutkan bahwa terdapat faktor - faktor pendorong baik dari internal (jumlah aset, CAR, DAR, dan CR) maupun eksternal (kondisi makro ekonomi) perusahaan yang dapat membantu Bank Syariah dalam memenuhi kinerja Maqashid Syariah. Faktor internal adalah pengambilan keputusan dan strategi-strategi operasional. Sedangkan faktor eksternal merupakan kebijakan moneter, tingkat inflasi, fluktuasi nilai tukar, dan inovasi instrumen keuangan (Anisa \& Tripuspitorini, 2020). Namun peneliti menemukan adanya perbedaan hasil penelitian dari penelitian - penelitian tersebut, sehingga penulis melakukan penelitian untuk menganalisis variabel independen yang sudah digunakan oleh penelitian sebelumnya, yaitu bank size (jumlah aset), CAR, PDB, inflasi, dan kurs terhadap kinerja BUS yang diukur dengan Maqashid Syariah Index (MSI).

\section{Kajian Pustaka}

\subsection{Maqashid SyariahIndex}

Secara bahasa Maqashid Syari'ah terdiri atas dua kata yaitu "maqashid" dan "syari'ab". Kata maqashid merupakan bentuk jama' dari maqshad atau maqshid yang berasal dari suku kata qashada yang berarti menghendaki, memaksudkan atau tujuan, sehingga maqashid berarti hal - hal yang dikehendaki dan dimaksudkan. Sedangkan syariah secara bahasa berarti jalan menuju sumber air, atau dapat diartikan juga sebagai jalan menuju sumber kehidupan (Elahi, 2010).

Mohammed dan Taib dalam pe nelitiannya yang berjudul The Performance Measures of ISlamic Banking Based on the Maqashid Framework telah merumuskan suatu pengukuran kinerja Bank Syariah yang tidak hanya fokus pada pemenuhan legalitas, namun jauh lebih kepada aspek ekonomi dan sosial. Alat ukur tersebut adalah Maqashid Syariah Index (MSI). Maqashid Syariah Index adalah suatu konsep penilaian kinerja yang dapat digunakan oleh Bank Syariah untuk menilai kinerja yang mengarah kepada tujuan Syariah. Dalam buku Ushul Figh dari Abu Zahrah, teori maqashid syariah mengacu pada 3 tujuan utama, meliputi (1) Tabdzib Al-Fard (mendidik individu), (2) Iqamah Al-Adl (menegakkan keadilan), dan (3) Maslahah (kesejahteraan) (Mohammed, Razak, \& Taib, 2008). Menurut Mohammed teknik pengelolaan data untuk mengukur Indeks Maqashid Syariah pada Bank Umum Syariah adalah menggunakan dua pendekatan yaitu Simple Additive Weight (SAW) dan Metode Sekaran. Simple Additive Weight (SAW) adalah metode yang menggunakan konsep penjumlahan terbobot, dimana penjumlahan terbobot tersebut dicari dari rating kinerja pada setiap alternatif pada semua atribut (Pahlevy, 2010).

\subsection{Bank-spesific Factors}

a. Bank Size

Bank Size atau ukuran bank adalah aspek yang menggambarkan kekayaan yang dimiliki oleh suatu bank. Selanjutnya aspek ini dapat dipresentasikan kedalam jumlah aset yang dimiliki 
bank. Aset adalah sarana atau sumber daya yang memiliki nilai ekonomis yang mampu menunjan perusahaan dalam harga perolehannya atau nilai wajarnya harus diukur secara objektif (Munawir, 2007: 30). Aset adalah manfaat ekonomis yang akan diterima pada masa mendatang, atau akan dikuasai oleh perusahaan sebagai hasil dari transaksi atau kejadian (Hanafi \& Mamduh, 2003). Dengan aset yang banyak pula mencerminkan bahwa profitabilitas bank sangat baik dan bank dapat menjalankan dan memenuhi kewajiban kewajibannya (Baridwan \& Zuhrotun, 2005).

b. CAR (Capital Adequacy Ratio)

Menurut Mudrajad dan Suhardjono (2011:519), Capital Adequacy Ratio adalah rasio yang menunjukkan kemampuan bank dalam mempertahankan modal yang mencukupi dan kemampuan manajemen bank dalam mengidentifikasi, mengukur, mengawasi, dan mengontrol risiko yang timbul dan mempengaruhi besarnya modal bank. CAR merupakan rasio yang menunjukkan seberapa jauh seluruh aktiva bank yang mengandung risiko untuk dibiayai dari dana modal bank sendiri (Dendawijaya, 2005).

\subsection{Faktor MakroEkonomi}

a. Produk Domestik Bruto

PDB (Produk Domestik Bruto) merupakan gambaran nilai barang dan jasa yang dapat dihasilkan oleh suatu negara dalam periode tahun tertentu (Sukirno, 2006: 17). Menurut Badan Pusat Statistik, Produk Domestik Bruto (PDB) merupakan salah satu indikator penting untuk mengetahui kondisi ekonomi di suatu negara dalam suatu periode tertentu.

b. Inflasi

Inflasi merupakan kenaikan harga secara umum dari barang atau jasa selama suatu periode tertentu. Tingkat inflasi diukur dengan menggunakan perubahan tingkatan harga secara umum, biasanya tingkatan harga yang digunakan adalah indeks harga konsumen (consumerprice index), indeks harga produsen (producerprice index) atau implicit gross domestic product deflator (GDP deflator) yang mengukur rata-rata harga seluruh barang tertimbang dengan kuantitas barangbarang yang betul-betul dibeli (Karim. 2008: 135 - 136). Inflasi juga dapat dikatakan sebagai fenomena moneter karena adanya penurunan nilai unit perhitungan moneter pada suatu komoditas tertentu. Sehingga, terjadi penurunan daya beli uang atau decreasing purchasing power of money (Fathonah \& Hermawan, 2020). Inflasi merupakan variabel makroekonomi yang digunakan untuk menjelaskan kenaikan harga umum secara terus-menerus dari suatu perekonomian (Huda dkk, 2009). Mankiw (2006) menjelaskan bahwa inflasi menurut pandangan masyarakat awam merupakan masalah sosial karena perubahan tingkat harga berhubungan dengan perubahan daya beli atau nilai uang. Selanjutnya Hasyim (2016) menjelaskan pula bahwa kenaikan harga - harga menimbulkan efek yang buruk terhadap perdagangan. Komoditas ekspor tidak akan bisa bersaing di pasar internasional. Sementara di lain pihak, harga komoditas dalam negeri naik dan harga impor justru menjadi relatif lebih murah. Akibatnya kuantitap impor akan lebih banyak dari pada ekspor, sehingga cadangan devisa semakin berkurang dan neraca pembayaran akan lebih buruk.

c. Kurs

Kurs merupakan harga suatu mata uang relatif terhadap mata uang negara lain. Kurs memainkan peranan penting dalam keputusan-keputusan pembelanjaan, karena kurs memungkinkan kita menerjemahkan hargaharga dari berbagai negara ke dalam satu bahasa yang sama (Ekananda, 2014: 168). Sedangkan yang dimaksud kurs BI adalah kurs standar yang ditetapkan oleh Bank Indonesia pada bursa valuta di Jakarta. Pada kurs BI terdapat dua jenis yaitu kurs jual dan kurs beli. 


\section{Metode Penelitian}

Metode penelitian ya ng digunakan pada penelitian ini adalah metode deskriptif kuantitatif. Adapun populasi yang diambil adalah Bank Umum Syariah di Indonesia yang tercatat di Otoritas Jasa Keuangan (OJK). Sumber data yang digunakan meliputi data sekunder yang diperoleh dari laporan tahunan B ank Umum Syariah di Indonesia, laporan ekonomi makro Badan Pusat Stattistik (BPS), dan laporan ekonomi makro Bank Indonesia. Pemilihan sampel menggunakan metode purposive sampling, yaitu teknik penentuan sampel d engan pertimbangan tertentu (Sugiyono, 2016:124). Adapun ketentuan p engambilan sampel pada penelitian ini adalah bank yang konsisten beroperas i sebagai Bank Umum Syariah di Indonesia selama 5 tahun terakhir, yaitu dari tahun 2014 sampai dengan 2018. Berdasarkan data statistik perbankan syariah yang dilaporkan oleh OJK, Bank Umum Syariah yang konsisten beroperasi selama 5 tahun tersebut berjumlah 12 bank, diantaranya:

a. Bank Muamalat Indonesia (BMI)

b. Bank Victoria Syariah (BVS)

c. Bank BRI Syariah (BRIS)

d. Bank Jabar Banten Syariah (BJBS)

e. Bank BNI Syariah (BNIS)

f. Bank Syariah Mandiri (BSM)

g. Bank Mega Syariah (BMS)

h. Bank Panin Syariah (BPnS)

i. Bank Syariah Bukopin (BSB)

j. Bank BCA Syariah (BCAS)

k. Maybank Syariah Indonesia (MSI)

1. Bank Tabungan Pensiunan Nasional Syariah (BT PNS)

Adapun definisi operasional penelitian ini dapat dilihat pada tabel berikut.

Tabel 1. Definisi dan Operasional Variabel

\begin{tabular}{|c|c|c|}
\hline Variabel & Keterangan & Sumber \\
\hline \multicolumn{3}{|l|}{ Variabel Dependen } \\
\hline Indeks Maqasbid Syariah & $\begin{array}{l}\text { Jumlah terbobot dari ketiga tujuan } \\
\text { maqasbid syariab। }\end{array}$ & Laporan Tahunan masing - masing BUS \\
\hline \multicolumn{3}{|l|}{ Variabel Independen } \\
\hline Bank Size & Nominal jumlah Aset & Laporan Tahunan masing - masing BUS \\
\hline CAR & $\begin{array}{l}\text { Persentase proporsi modal } \\
\text { terhadap total aktiva }\end{array}$ & Laporan Tahunan masing - masing BUS \\
\hline PDB & $\begin{array}{l}\text { Nomilah jumlah PDB Bruto } \\
\text { (Lapangan Usaha) }\end{array}$ & $\begin{array}{l}\text { Laporan data Pendapatan Nasional } \\
\text { Badan Pusat Statistik (BPS) }\end{array}$ \\
\hline Inflasi & Persentase inflasi & $\begin{array}{l}\text { Laporan Kebijakan Moneter Indonesia - } \\
\text { Bank Indonesia (BI) }\end{array}$ \\
\hline Kurs & $\begin{array}{l}\text { Nominal nilai kurs tengah Rupiha } \\
\text { terhadap dollar Amerika }\end{array}$ & $\begin{array}{l}\text { Laporan Kebijakan Moneter Indonesia - } \\
\text { Bank Indonesia (BI) }\end{array}$ \\
\hline
\end{tabular}

Sumber : diolah penulis

Teknik analisis data pada penelitian ini menggunakan teknik analisis statistik deskriptif dengan metode analisis regresi data panel. Pengumpulan dan pengolahan data menggunakan perangkat 
lunak Microsoft Excel dan Eviews 10.

\section{Hasildan Pembahasan}

\subsection{Analisis Deskriptif}

Pada penelitian ini variabel yang digunakan adalah variabel independen diantaranya, bank size (jumlah aset bank), CAR (Capital Adequacy Ratio), produk domestik bruto, inflasi, dan kurs atau nilai tukar. Sedangkan variabel dependen adalah kinerja Bank Syariah yang dipresentasikan oleh nilai indeks maqashid sharia. Berikut ini adalah hasil output dari analisis deskriptif setiap variabel penelitian.

Tabel 2. Analisis Deskriptif

\begin{tabular}{|l|c|c|c|c|c|}
\hline & Mean & Median & Maximum & Minimum & Std. Dev. \\
\hline MSI & 0,280307 & 0,265166 & 0,49707 & 0,084155 & 0,104356 \\
\hline BS $\left(R_{p}\right)$ & 20.040 .285 & 7.150 .246 & 98.341 .116 & 661.912 & 24.900 .776 \\
\hline CAR & 0,24552 & 0,19275 & 1,6307 & 0,1151 & 0,215155 \\
\hline PDB $\left(R_{p}\right)$ & 12.600 .000 .000 & 12.400 .000 .000 & 14.800 .000 .000 & 10.600 .000 .000 & 1.520 .000 .000 \\
\hline INFLASI & 0,04294 & 0,0335 & 0,0836 & 0,0302 & 0,020602 \\
\hline KURS $\left(R_{p}\right)$ & 13.472 & 13.480 & 14.409 & 12.378 & 661 \\
\hline
\end{tabular}

Sumber: Output Eviews 10, diolah penulis

\subsection{Pemilihan Model Regresi Data Panel}

Sebelum mengestimasi model regresi data panel, diperlukan tahapan untuk memilih model terbaik. Menurut Widarjono (2007), terdapat tiga teknik untuk mengestimasi parameter model dengan data panel, yaitu Common Effect Model, Fixed Effect Model, dan Random Effect Model. Kemudian pemilihan model terbaik dari ketiga model tersebut dilakukan melalui beberapa tahapan pengujian, diantaranya:

a. Uji Chow

Uji Chow adalah pengujian untuk menentukan Common Effect Model atau Fixed Effect Model yang paling tepat digunakan dalam mengestimasi data panel. Adapun kriteria pengambilan keputusan adalah jika probabilitas $\mathrm{F}$ kurang dari 0,05 (sig. atau $\alpha=0,05$ ), maka $\mathrm{H}_{0}$ ditolak dan model yang terpilih adalah Fixed Effect Model. Namun jika probabilitas F lebih dari 0,05 (sig. atau $\alpha=0,05)$, maka $\mathrm{H}_{0}$ diterima dan model yang terpilih adalah Common Effect Model atau Pooled Least Square. Berikut adalah hasil Uji Chow yang dilakukan pada penelitian ini.

Tabel 3. Hasil Uji Chow

\begin{tabular}{|c|c|c|c|}
\hline Prob. F & Indikator & Hasil & Kesimpulan \\
\hline 0,0000 & $\begin{array}{c}\text { Prob. F < sig. } \\
(0,05)\end{array}$ & $\mathrm{H}_{0}$ ditolak & $\begin{array}{c}\text { Fixed Effect } \\
\text { Model terpilih }\end{array}$ \\
\hline
\end{tabular}

Sumber: Output Eviews 10, diolah penulis

b. Uji Hausman

Uji hausman adalah pengujian statistik untuk memilih apakah Fixed Effect Model atau Random Effect Model yang paling tepat digunakan. Kriteria pengambilan keputusan adalah jika probabilitas Chi square kurang dari 0,05 (sig. atau $\alpha=0,05$ ), maka $\mathrm{H}_{0}$ ditolak dan model yang terpilih adalah Fixed Effect Model. Namun jika probabilitas Chi square lebih dari 0,05 (sig. atau $\alpha$ $=0,05)$, maka $\mathrm{H}_{0}$ diterima dan model yang terpilih adalah Random Effect Model. Adapun hasil uji Hausman yang dilakukan pada penelitian ini adalah sebagai berikut. 
Tabel 4. Hasil Uji Hausman

\begin{tabular}{|c|c|c|c|}
\hline Prob. Chi sq & Indikator & Hasil & Kesimpulan \\
\hline 1,0000 & $\begin{array}{r}\text { Prob. Chi sq. } \\
>\text { sig. }(0,05)\end{array}$ & $\mathrm{H}_{0}$ diterima & $\begin{array}{r}\text { Random Effect } \\
\text { Model terpilih }\end{array}$ \\
\hline
\end{tabular}

Sumber: Output Eviews 10, diolah penulis

c. Uji Lagrange Multiplier

Uji Lagrange Multiplier adalah suatu analisis yang dilakukan untuk menentukan model terbaik diantara Random Effect Modeldan Common Effect Model. Adapun kriteria pengambilan keputusan pada uji Lagrange Multiplier adalah jika p value kurang dari 0,05 (sig. atau $\alpha=0,05$ ), maka $\mathrm{H}_{0}$ ditolak dan $\mathrm{H}_{\mathrm{a}}$ diterima, sehingga model yang terpilih adalah Random Effect Model. Namun jika $\mathrm{p}$ value lebih dari 0,05 (sig. atau $\alpha=0,05$ ), maka $\mathrm{H}_{0}$ diterima dan model yang terpilih adalah Common Effect Model. Berikut adalah hasil Uji Lagrange Multiplier yang dilakukan pada penelitian ini.

Tabel 5. Hasil Uji Lagrange Multiplier

\begin{tabular}{|c|c|c|c|}
\hline P. value & Indikator & Hasil & Kesimpulan \\
\hline 0,0000 & $\begin{array}{c}\text { P. value }<\text { sig. } \\
(0,05)\end{array}$ & $\mathrm{H}_{0}$ ditolak & $\begin{array}{c}\text { Random Effect } \\
\text { Model terpilih }\end{array}$ \\
\hline
\end{tabular}

Sumber: Output Eviews 10, diolah penulis

Berdasarkan hasil ketiga uji diatas dapat diambil kesimpulan bahwa model terbaik yang digunakan untuk penelitian ini adalah Random Effect Model.

\subsection{Hasil Analisis}

a. Uji Asumsi Klasik

Penelitian denga n menggunakan data panel memiliki kelebihan bahwa data yang digunakan akan menjadi lebih informatif, vvariabilitas lebih besar, kolineariti lebih rendah diantara variabel, dan banyaknya derajat bebas (degree of freedom), juga lebih efisien (Hariyanto , 2005). Oleh karena itu penulis memutuskan untuk tidak melakukan uji asumsi klasik, mengingat bahwa penelitian ini menggunakan regresi data panel dengan model yang terpilih adalah random effect model.

b. Estimasi Model Regresi dan Pengujian Hipotesis

Berikut adalah tabel estimasi dari Random Effect Model sebagai model terpilih pada penelitian ini.

Tabel 6. Estimasi Random Model Effect

\begin{tabular}{|c|c|c|}
\hline \multicolumn{3}{|c|}{ Dependent Variable: MSI (Magashid Sharia Index) } \\
\hline Variabel & Coefficient & Probabilitas \\
\hline BS & $-0,020110$ & 0,5316 \\
\hline CAR & $-0,094933$ & 0,0354 \\
\hline PDB & 0,439666 & 0,0218 \\
\hline Inflasi & 0,241623 & 0,6397 \\
\hline Kurs & $-0,207249$ & 0,7414 \\
\hline $\mathrm{C}$ & $-3,149450$ & 0,1440 \\
\hline$R$-squared & 0,161114 & \\
\hline Adjusted R-squared & 0,083439 & \\
\hline S.E. of regression & 0,040691 & \\
\hline F-statistic & 2,074210 & \\
\hline Prob. (F-statistic) & 0,082835 & \\
\hline
\end{tabular}

Sumber: Output Eviews 10, diolah penulis 
Berdasarkan tabel tersebut persamaan estimasi untuk model indeks maqashid syaria adalah sebagai berikut.

MSI $=$ - 3,149450 - 0,020110BS - 0,094933CAR + 0,439666PDB + 0,241623Inflasi -

0,207249Kurs

\subsection{Pembahasan}

a. Kemampuan Bank Size Mempengaruhi Maqashid Sharia Index

Berdasarkan hasil estimasi pada tabel 6 menunjukkan bahwa koefisien variabel bank size sebesar-0,020110 dengan nilai signifikansi sebesar 0,5316. Hal ini menunjukkan bahwa bank size berpengaruh negatif dan tidak signifikan terhadap indeks maqashid syariah pada Bank Umum Syariah di Indonesia karena nilai probabilitas dari variabel bank size lebih besar dari taraf signifikansi $(\alpha=0,05)$. Oleh karena itu dalam hal ini tinggi rendahnya bank size yang diukur oleh jumlah aset tidak berpengaruh terhadap kinerja yang dipresentasikan oleh Maqashid Sharia Index (MSI) pada setiap sampel penelitian. Dengan demikian hipotesis yang diajukan dimana bahwa bank size berpengaruh positif terhadap indeks maqashid syariah tidak terbukti.

Hasil penelitian ini tidak sejalan dengan penelitian yang dilakukan oleh Akbar (2013) dimana hasil dari penelitian tersebut menyebutkan bahwa ukuran perusahaan berpengaruh positif terhadap kinerja Bank Syariah. Namun hasil penelitian ini konsisten dengan hasil penelitian yang dilakukan oleh Gayatri dan Sutrisno (2017) yang menyatakan bahwa ukuran perusahaan tidak memiliki pengaruh terhadap kinerja Bank Syariah yang diukur menggunakan Maqashid Index. Kemudian hasil penelitian ini juga mendukung hasilpenelitian yang dilakukan oleh Larasati dan Adityawarman (2016) yang menyatakan bahwa besarnya aset bank tidak mempunyai pengaruh langsung terhadap kinerja Bank Syariah, karena ada kaitannya dengan pemilihan sumber dana berupa liabilitas yang besar, sehingga aset yang besar berasal dari liabilitas yang besar pula. Dengan demikian tingkat risiko akan lebih tinggi dan tidak berpengaruh terhadap kinerja Bank Syariah.

Besarnya jumlah aset pada perusahaan mempengaruhi kegiatan perusahaan, salah satunya adalah monitoring sumber dana dan penggunaanya. Bank dengan aset yang besar menandakan banyak melakukan aktivitas, yang berdampak juga pada banyaknya jumlah dana simpanan dan juga modal perusahaan. Mengingat modal bank salah satunya terdiri dari modal investor, menjadikan bank mempunyai tanggungjawab dalam pengembalian kepada investor. Namun banyaknya aset bank tidak menutup kemungkinan akan digunakan untuk hal diluar kepentingan bersama, karena pada hakikatnya manusia ingin memperkaya diri sendiri. Hal ini dapat diatasi dengan misalnya melakukan monitoring atau bonding (pembatasan wewenang) terhadap pihak bank yang dilakukan oleh pihak luar, tetapi akan menguras dana cukup besar, sehingga akan menambah risiko bank.

Berdasarkan teori agensi menyatakan bahwa semakin besar ukuran perusahaan berpengaruh juga terhadap kompleks konflik keagenan yang dihadapi perusahaan.Pada dasarnya perusahaan yang besar memiliki kekuatan finansial yang lebih besar dalam menghasilkan kinerja yang semakin baik. Namun disisi lain perusahaan dengan ukuran yang besar sulit untuk melakukan monitoring, sehingga menyebabkan meningkatnya biaya agensi (agencycost) (Rajha \& Zaher, 2014).

b. Kemampuan CAR Mempengaruhi Maqashid Sharia Index

Berdasarkan hasil estimasi pada tabel 6 menunjukkan bahwa koefisien variabel CAR sebesar 0,094933 dengan nilai signifikansi sebesar 0,0354. Hal ini menunjukkan bahwa CAR berpengaruh negatif dan signifikan $(\alpha=0,05)$ terhadap indeks maqashid syariah pada Bank Umum Syariah di Indonesia. Nilai koefisien CAR sebesar -0,094933 juga menunjukkan bahwa setiap kenaikan 1\% akan diikuti oleh penurunan indeks maqashid syariab sebesar $9.4933 \%$. Dengan demikian hasil penelitian ini sesuai dengan hipotesis yang diajukan 
dimana bahwa CAR (Capital Adequacy Ratio) berpengaruh negatif terhadap indeks maqashid sharia.

Hasil penelitian ini tidak sejalan dengan hasil penelitian oleh Widiastuty (2019) yang menyatakan bahwa risiko permodalan yang dinyatakan dalam Capital Adequacy Ratio (CAR) tidak mempunyai pengaruh terhadap pendistribusian zakat, dimana merupakan salah satu komponen dari kinerja Maqashid Sharia. Namun hasil penelitian ini konsisten dengan hasil penelitian oleh Larasati dan Adityawarman (2016) yang menyatakan bahwa rasio kecukupan modal memiliki pengaruh negatif terhadap kinerja Bank Syariah. Kemudian hasil penelitian ini juga mendukung penelitian yang dilakukan oleh Gayatri dan Sutrisno (2017) yang menyatakan bahwa semakin tinggi nilai CAR yang dimiliki suatu Bank Syariah mengakibatkan kinerja Maqashid Sharia Bank Syariah semakin rendah.

Secara langsung Capital Adequacy Ratio memang tidak mempengaruhi pengungkapan tentang zakat pada Bank Syariah melainkan berkaitan dengan modal dan aktiva tertimbang menurut risiko dalam hal ini piutang (pembiayaan). Akan tetapi apabila Capital Adequacy Ratio semakin tinggi maka pembiayaan yang bermasalah semakin besar dan akan mempengaruhi keuntungan yang diperoleh Bank Syariah. Hal ini selanjutnya akan mengakibatkan pendistribusian zakat semakin rendah. rendahnya pendistribusian zakat akan mengakibatkan rendahnya nilai Maqashid Shariah bank yang bersangkutan.

Bank yang mempunyai tingkat CAR tinggi artinya struktur modal bank yang bersangkutan sangat besar untuk penggunaan operasional bank. Hal ini seharusnya akan meningkatkan kinerja bank. Namun hasil dari penelitian ini, tingkat CAR yang semakin besar akan membuat kinerja Bank Syariah yang diukur oleh Maqashid Syariah akan semakin menurun. Hal ini disebabkan oleh beberapa faktor yang merubah hasil tersebut, baik dari anomali pasar maupun kondisi lainnya. Kondisi tersebut salah satunya dapat disebabkan karena adanya pembiayaan yang bermasalah. Modal yang digunakan Bank Syariah untuk melakukan pembiayaan tidak menghasilkan keuntungan bagi Bank Syariah, sehingga menimbulkan risiko bank. Kemudian untuk menutupi kerugian dari banyaknya pembiayaan bermasalah pada Bank Syariah yang bersangkutan, bank diharuskan menggunakan modal untuk menutupi risiko - risiko tersebut dan karenanya penggunaan modal tidak maksimal untuk kegiatan bank. Dengan demikian tingginya tingkat CAR Bank Syariah akan berpengaruh pada besarnya kinerja bank yang diukur oleh Maqashid Syariab Index, mengingat komponen pada perhitungan kinerja tersebut adalah jumlah pembiayaan dan ROA.

Menurut Sutrisno (2009), semakin tinggi nilai Capital Adequacy Ratio pada suatu bank artinya bank terlalu banyak mengalokasikan dananya ke dalam modal sehingga dana yang digunakan untuk melakukan pembiayaan, membayar biaya karyawan, dan mendistribusikan zakat semakin sedikit dan berpengaruh pada nilai kinerja bank terutama pada nilai Maqashid Sharia Index (MSI). Hal ini dikarenakan komponen nilai - nilai maqashid sharia dalam perhitungannya terdapat nilai keuntungan (ROA), biaya kesejahteraan karyawan,jumlah pengeluaran untuk zakat, dan besar pembiayaan yang dilakukan. Menurut Mawardi (2005), apabila nilai CAR suatu bank lebih dari ketetapan Bank Indonesia yaitu sebesar 8\%,maka terjadi idle money, karena pada hakikatnya modal-utama suatu bank adalah kepercayaan. Secara realitassuatu bank yang profitable tidak hanya mempunyai CAR kurang dari 8\% akan tetapi juga memiliki dan memeganga kepercayaan masyarakat.

c. Kemampuan PDB Mempengaruhi Maqashid Sharia Index

Berdasarkan hasil estimasi pada tabel 6 menunjukkan bahwa koefisien variabel PDB sebesar 0,439666 dengan nilai signifikansi sebesar 0,0218. Hal ini menunjukkan bahwa PDB berpengaruh positif dan signifikan $(\alpha=0,05)$ terhadap indeks maqashid syariah pada Bank Umum Syariah di Indonesia selama periode penelitian. Nilai koefisien PDB sebesar 0,439666 juga menunjukkan bahwa setiap kenaikan 1\% akan diikuti oleh peningkatan indeks 
maqashid shariah sebesar 43.9666\%. Dengan demikian hasil penelitian ini sesuai dengan hipotesis yang diajukan dimana bahwa PDB berpengaruh positif terhadap indeks maqashid sharia.

Hasil penelitian ini sejalan dengan hasil penelitian Syahbudi dan Saragih (2018) yang menyatakan bahwa PDB memiliki kemampuan dalam mempengaruhi pembiayaan,dimana semakin tinggi PDB menunjukkan peningkatan terhadap pembiayaan dan berpengaruh langsung dengan nilai Maqashid Sharia Index. Kemudian hasil penelitian ini mendukung hasil penelitian oleh Irsyad, Kosim, dan Hakim (2017) yang menyatakan bahwa variabel PDB memiliki pengaruh positif dan signifikan terhadap kinerja Bank Syariah yang diukur oleh ROA (Return On Asset) dan secara langsung mempengaruhi nilai Maqashid Sharia Index.

Tingginya pertumbuhan ekonomi Indonesia yang diukur oleh PDB menyebabkan tinggi pula kinerja bank yang diukur oleh Maqashid Syariah. Hal ini disebabkan karena beberapa faktor, diantaranya meningkatnya kesejahteraan masyarakat. Peningkatan tersebut menjadikan masyarakat melakukan kegiatan saving pada Bank Syariah, kemudian Bank Syariah banyak menyalurkan dana pada masyarakat, berupa pembiayaan maupun zakat, dan juga pada sektor riil. Dengan demikian banyak jumlah pembiayaan dan porsi zakat yang disalurkan akan meningkatkan kinerja Bank Syariah yang diukur oleh Maqashid Syariah Index.

Produk domestik bruto merupakan alat ukur ekonomi untuk menilai perkembangan ekonomi suatu Negara dan mempunyai ukuran makro utama tentang kondisi suatu Negara (Huda, 2013). Menurut Sukirno (2012), apabila PDB naik maka akan diikuti peningkatan pendapatan masyarakat, sehingga kemampuan untuk menabung (saving) juga meningkat. Peningkatan saving ini dapat mempengaruhi profitabilitas Bank Syariah . Peningkatan profit Bank Syariah berdampak pada pemenuhan kewajiban - kewajiban sosial Bank Syariah semakin meningkat juga.Seperti dengan meningkatnya profit bank dapat membayar zakat lebih banyak, sehingga kinerja maqashid syariah semakin baik (Putrie,2018).

d. Kemampuan Inflasi Mempengaruhi Maqashid Sharia Index

Berdasarkan hasil estimasi pada tabel 6 menunjukkan bahwa koefisien variabel inflasi sebesar 0,241623 dengan nilai signifikansi sebesar 0,6397. Hal ini menunjukkan bahwa inflasi berpengaruh positif dan tidak signifikan terhadap indeks maqashid syariah pada Bank Umum Syariah di Indonesia karena nilai probabilitas dari variabel inflasi lebih besar dari taraf signifikansi ( $\alpha=0,05)$. Oleh karena itu dalam hal ini tinggi rendahnya inflasi tidak berpengaruh terhadap kinerja yang dipresentasikan oleh Maqashid Sharia Index (MSI) pada setiap sampel penelitian. Dengan demikian hipotesis yang diajukan dimana bahwa inflasi berpengaruh positif terhadap indeks maqashid syariah tidak terbukti.

Hasil penelitian ini tidak mendukung hasil penelitian yang dilakukan oleh Hidayati ( 2014) yang menyatakan bahwa inflasi mempunyai pengaruh positif dan signifikan terhadap kinerja profitabilitas Bank Syariah, yang merupakan salah satu alat ukur Maqashid Sharia Index. Namun hasil penelitian ini konsisten dengan hasil penelitian oleh Widiastuty (2019) yang menyatakan bahwa tingkat inflasi tidak mempunyai pengaruh yang signifikan terhadap kinerja Bank Syariah yang diukur oleh Maqashid Index. Bank Syariah sebagai perusahaan yang menjunjung tinggi nilai Islam berkewajiban untuk mengeluarkan sebagian harta perusahaan untuk dibayarkan zakat. Bank Syariah menganggap hal ini sebagai bentuk menjalankan salah satu perintah Allah SWT, sehingga besarnya inflasi tidak mempengaruhi besar pengeluaran zakat yang merupakan salah satu komponen dalam Maqashid Sharia Index (MSI).

Kemudian penelitian lain yang mendukung hasil penelitian ini adalah hasil penelitian dari Suprihatin (2017) yang menyatakan bahwa variabel inflasi tidak berpengaruh terhadap pembiayaan pada Bank Umum Syariah di Indonesia yang merupakan alat ukur kinerja Maqashid Sharia. Pada penelitian tersebut menunjukkan peningkatan laju inflasi tidak 
mengurangi kegiatan Bank Syariah dalam melakukan pembiayaan. Mahalnya harga barang akibat meningkatnya inflasi tidak mempengaruhi Bank Syariah untuk menyalurkan dana melalui pembiayaan, sehingga secara langsung tidak mempengaruhi kinerja Maqashid Sharia pada Bank Syariah.

e. Kemampuan Kurs Mempengaruhi Maqashid Sharia Index

Berdasarkan hasil estimasi pada tabel 6 menunjukkan bahwa koefisien variabel inflasi sebesar $-0,207249$ dengan nilai signifikansi sebesar 0,7414. Hal ini menunjukkan bahwa kurs atau nilai tukar berpengaruh negatif dan tidak signifikan terhadap indeks maqashid sharia pada Bank Umum Syariah di Indonesia karena nilai probabilitas dari variabel kurs lebih besar dari taraf signifikansi $(\alpha=0,05)$. Oleh karena itu dalam hal ini tinggi rendahnya nilai tukar rupiah tidak berpengaruh terhadap kinerja yang dipresentasikan oleh Maqashid Sharia Index (MSI) pada setiap sampel penelitian. Dengan demikian hipotesis yang diajukan dimana bahwa kurs berpengaruh negatif dan signifikan terhadap indeks maqashid sharia tidak terbukti.

Hasil penelitian ini tidak sejalan dengan hasil penelitian yang dilakukan oleh Hidayati (2014) yang menyatakan bahwa kurs mempunyai pengaruh signifikan terhadap kinerja Bank Syariah. Namun hasil penelitian ini selaras dengan hasil penelitian oleh Hendratno dan Winarno (2019) yang menyebutkan bahwa kurs atau nilai tukar secara parsialtidak berpengaruh terhadap kinerja profitabilitas Bank Syariah sebagai komponen Maqashid Shariah Index. Hasil penelitian ini juga konsisten dengan hasil penelitian yang dilakukan oleh Dwitama dan Widiastuti (2016) yang menyatakan bahwa kurs tidak berpengaruh pada kinerja Bank Syariah dalam hal pendistribusian zakat sebagai komponen Maqashid Shariah Index.

Sejak pertengahan Juli 1997 sistem nilai tukar yang diterapkan pada perekonomian Indonesia adalah sistem nilai tukar mengambang (Free Floating Exchange Rate System). Sistem ini menyerahkan nilai tukar sepenuhnya diatur oleh pasar, yakni ditentukan oleh besar demand dan supply untuk mencapai ekuilibrium, sehingga dalam sistem nilai tukar ini hampir tidak ada campur tangan pemerintah. Besar kecilnya nilai tukar dapat berubah setiap harinya. Hal ini dapat disebabkan oleh beberapa faktor salah satunya disebabkan oleh aksi ambil untung (profit taking) oleh pelaku pasar. Hal ini sangat dilarang oleh Islam karena terdapat unsur spekulasi atau maysir. Oleh karena itu sebagai bank yang menganut aturan Syariah kegiatan operasional Bank Syariah seperti pemberian pembiayaan dan penghimpunan dana sangat meminimalisir penggunaan transaksi valuta asing, sehingga tidak terlalu dipengaruhi oleh kondisi nilai tukar rupiah terhadap dolar (Ahmad, 2011).

Menurut (Riantor \& Arif, 2010), untuk menghindari unsur keharaman dari sistem nilai tukar, perekonomian Indonesia dapat kembali pada sistem kurs mengambang terkendali (Managed Floating Exchange Rate) seperti pada tahun 1978 silam, dimana penetapan nilai tukar tetap diatur berdasarkan aktivitas pasar valuta namun terdapat campur tangan pemerintah. Pemerintah yang dimaksudkan adalah Bank Indonesia, sebagai lembaga regulasi kebijakan moneter Indonesia. Bank Indonesia dapat mengatur supaya unsur maqghrib (maysir, gharar, dan riba) dapat diminimalisir pada aktivitas pasar valuta.

f. Kemampuan Kurs Mempengaruhi Maqashid Sharia Index

Berdasarkan hasil estimasi pada tabel 6 menunjukkan nilai probabilitas (F-statistic) sebesar 0,082835 .Nilai tersebut lebih besar dari taraf signifikansi $(\alpha=0,05)$ dan menunjukkan bahwa secara simultan variabel independen tidak berpengaruh terhadap indeks maqashid sharia. Dengan demikian hipotesis yang diajukan menerima $\mathrm{H}_{0}\left(\right.$ menolak $\left.\mathrm{H}_{\mathrm{a}}\right)$ yang artinya bahwa semua variabel independen secara bersama - sama tidak mempengaruhi indeks maqashid sharia. Kemudian pada tabel estimasi dapat diketahui pula bahwa nilai R-squared 
sebesar 0,161114. Nilai tersebut menunjukkan bahwa kemampuan variabel bank size, CAR, PDB, inflasi, dan kurs dalam menjelaskan variabel dependen yaitu indeks maqashid sharia sebesar $16.1114 \%$. Dengan demikian $83.8886 \%$ berasal dari variabel lain diluar penelitian ini yang dapat menjelaskan variabel indeks maqashid syariah.

\section{Penutup}

Berdasarkan analisis yang telah dilakukan dan mengacu pada hasil penelitian yang telah dibahas, maka kesimpulan yang dapat diangkat pada penelitian ini adalah sebagai berikut.

1. Pada variabel bank size, inflasi, dan kurs tidak mempunyai pengaruh yang signifikan terhadap kinerja Maqashid Syariah. Sedangkan variabel CAR mempunyai pengaruh signifikan dan negatif terhadap kinerja Maqashid Syariah dan variabel PDB mempunyai pengaruh signifikan dan positif terhadap kinerja Maqashid Syariah.

2. Pada hasil penelitian menunjukkan bahwa variabel bank size, CAR, PDB, inflasi, dan kurs secara simultan tidak mempunyai pengaruh signifikan terhadap kinerja Maqashid Syariah.

Pengungkapan maqashid sharia index pada Bank Syariah belum maksimal dan belum konsisten dilakukan padahal hal ini bisa menjadi indikator bagi Bank Syariah untuk menilai kinerja sosial perusahaan sesuai tujuan Syariah dan memberi kepercayaan lebih kepada masyarakat muslim. Dengan mengetahui indeks Maqashid Syariah pada bank syariah beserta faktor yang mempengaruhinya, diharapkan dapat membantu manajemen Bank Umum Syariah untuk mengevaluasi kinerjanya dalam pencapaian tujuan Syariah dan mengambil kebijakan yang selaras dengan kondisi internal dan eksternal bank sehingga tetap pada prinsip Syariah. Dengan begitu Bank Syariah di Indonesia dapat menjadi lembaga yang konsisten pada prinsip Syariah.

Untuk penelitian selanjutnya dapat menambah variabel - variabel lain, khususnya pada variabel independen, mengingat dari hasil analisis r-square pada estimasi model hanya sebesar $16 \%$. Artinya terdapat $84 \%$ diluar variabel penelitian ini yang dapat digunakan, baik dari faktor internal Bank Syariah maupun faktor eksternal Bank Syariah.

\section{DaftarPustaka}

Anisa, L. T. \& Afiyanti, F. T. (2019). Analisis Pengaruh Dana Pihak Ketiga, Non Performing Finance Murabahah, dan Inflasi terhadap Pembiayaan Murabahah pada Bank Umum Syariah di Indonesia. Jurnal MAPS, 52-64.

Antonio, Sanrego, dan M. Taufiq. (2012): An Analysis of Islamic Banking Performance: Maqashid Index Implementation in Indonesia and Jordania. IIUM Institute of Islamic Banking and Finance. Journal of Islamic Finance. Vol 1(1).

Dendawijaya, L. (2005). Manajemen Perbankan. Bogor: Ghalia Indonesia.

Elahi, Dr. Mohammad Monzur E. (2010): The Objectives and Intents of Islamic Shariah as a Paradigm of Development Strategies and Policies. IIUC Studies 7, Hal 321- 336. ISSN 18137733.

Fathonah, A. S., \& Hermawan, D. (2020). Estimasi Pengaruh Faktor Internal Bank dan Stabilitas Makroekonomi terhadap Profitabilitas dengan Mediasi Rasio Pembiayaan Bermasalah di PT Bank Muamalat Indonesia. Jurnal Manajemen Perbankan Syariah (MAPS), 93-108.

Gayatri, Anggita Dwi dan Sutrisno. (2017): Analisis Pengarub Produk dan Risiko Bank terbadap Kinerja Maqasid Al Shariah Studi Kasus pada Perbankan Syariah di Indonesia. Skripsi. Surakarta: Universitas Muhammadiyah Surakarta.

Hanafi, Mamduh H dan A. Halim. (2007): Analisis Laporan Keuangan, edisi 3. Yogyakarta: Penerbit UPP STIM YKPN. 
Huda N, Idris HR, Nasution ME, Wiliasih R. (2009): Ekonomi Makero Islam: pendekatan teoritis edisi ke2. Jakarta (ID): Kencana Prenada Media Group

Karim, Adiwarman A. (2008): Ekonomi Mikro Islami. Jakarta: PT. Raja Grafindo Persada

Larasati Anuttara E.D., Adityawarman. (2016). Pengaruh Struktur Modal dan Krakteristik Bank terhadap Kinerja Keuangan Bank Syariah. Dipenogoro Journal of Accounting, hlm 1-10.

Mankiw NG. (2006): Makroekonomi Edisi ke-6. Liza F, Nurmawan I, penerjemah; Harnadi W, Barnadi D, Saat S, editor. Jakarta (ID): Erlangga.

Mohammed, Dzuljastri, dan Taib. (2008): The Performance Measures of Islamic Banking Based on the Maqasid Framework. IIUM International Accounting Conference (INTAC IV). International Islamic University Malaysia.

Mohammed, M. O., Razak, D. A., \& Taib, F. M. (2008). The Performance Measures of ISlamic Banking Based on the Maqashid Framework. Paper of IIUM International Accounting Conference (INTAC IV) held at Putra Jaya Marroitt, 1-17.

Munawir. (2007): Analisis Laporan Kenangan. Yogyakarta: Edisi Empat, Liberty.

Putrie. (2018). Analisis Pengaruh ROA terhadap Zakat pada Bank Syariah.

Rajha, K., Zaher, A. (2014). The Effect of Capital Structure on the Performance of Islamic Banks. Interdisciplinary Journal of Contemporary Research in Business, Vol.5 No.9

Setiawan, S., Wulansari, P., \& Kusuma Dewi, R. (2020). Pengukuran Tingkat Kinerja Keuangan dan Kinerja Non Keuangan pada Bank Syariah di Lima Negara Asia (Studi Kasus pada Bank Syariah dengan Aset Tertinggi). Dinamika Akuntansi Keuangan Dan Perbankan, 9(1), 69 - 78.

Sugiyono. (2015): Metodologi Penelitian Kuantitatif, Kualitatif dan R $\delta D$.Bandung: Alfabeta, Hlm. 7.

Sukirno, Sadono. (2012). Makroekonomi Teori Pengantar. Jakarta: PT Raja Grafindo Persada.

Sutrisno dan Agus Widarjono. (2018): Maqashid Sharia Index, Banking Risk, and Performance Cases in Indonesian Islamic Banks. Asian Economic and Financial Review. Vol. 8, No. 9, 11751184.

Syahbudi M., Saragih. (2018). Pengarub V ariabel Makro Ekonomi terhadap Pembiayaan pada Perbankan Syariah di Indonesia. Skripsi. Universitas Islam Negeri Sumatera Utara Medan.

Widarjono, Agus. (2009): Ekonometrika Pengantar dan Aplikasinya Edisi Ketiga. Yogyakarta: Ekonisia.

Widiastuty, Tri. (2019). Peran Ukuran Bank, Risiko Permodalan, dan Tingkat Inflasi terhadap Pengeluaran Zakat Bank. Umum Syariah. Prociding Seminar Nasional, hlm 1-6. 